\title{
Evaluation of Maritime Tourism Development in Muna Regency in Southeast Sulawesi
}

\author{
Laode Kadar $^{1 *}$, Juhasdi Susono ${ }^{2}$, Abdul Rahim ${ }^{3}$ \\ Universitas Negeri Jakarta, Jakarta , Indonesia \\ 2 \\ juhasdimm@gmail.com, ${ }^{3}$ rahimilmi72@gmail.com
}

\begin{abstract}
Broadly speaking, this study aims to obtain the results of a study regarding the evaluation of the development of marine tourism in Muna Regency in Southeast Sulawesi. The unit of analysis in this study is the Office of Tourism and Culture as one of the government agencies in Muna Regency, which is demanded to manage and contribute to the maximum revenue contribution to the Regional Original Revenue (PAD) with selected respondents and key informants are the Head of Service, Head of Division and Head of Planning and Financial Subdivision. In this study the research method used is descriptive qualitative method. The analysis tool used is the Realistic Evaluation Method with the Context-Mechanism-Outcome configuration approach. The results showed that, evaluation of the development of marine tourism in Muna Regency through the analysis of Context and Mechanism evaluation can be obtained Outcome
\end{abstract}

Keywords - Evaluation, Development and Maritime Tourism

\section{INTRODUCTION}

Tourism is present as a new economic icon in development, both on a regional and national scale which certainly contributes to the socio-economic well-being of people's lives. In today's development, tourism is considered a productive sector that can be used as a mainstay sector in moving the wheels of development to increase local revenue which ultimately leads to better economic growth.

The Indonesian government has realized the importance of tourism development in promoting national economic growth. As explained in Law Number 10 Year 2009 article 4, national tourism development aims to increase economic growth, improve people's welfare, eradicate poverty, overcome unemployment, preserve nature, the environment and resources, advance culture, uplift the nation's image, foster a sense of love homeland, strengthen national identity and unity, and strengthen friendship between nations. 
Like Muna Regency, it is one of the districts located in the corner of the peninsula of Southeast Sulawesi Province as an archipelago province and is located in eastern Indonesia. In its development, marine tourism in Muna Regency is still not maximized. Budget and infrastructure problems have become the main obstacles for advancing marine tourism in Muna Regency, road damage and poor asphalt quality make it difficult for tourists to access tourist sites, the unavailability of public transportation to reach tourist sites makes visitors hampered through site visit activities, the absence of signs or road directions make tourists confused in getting information, not yet again the lack of facilities such as the availability of food stalls, lack of availability of toilet facilities, the unavailability of resorts or home stays close to tourist sites make tourists think twice and even become lazy to visit tourist destinations, especially marine tourism in Muna Island. While all of these are important aspects and are needed by tourists.

Based on a report published by Agus [1], the Muna Regency Regional Expenditure Budget in 2017 amounted to 1.1 trillion while the budget portion for the tourism sector was very minimal, namely 3 billion, then in 2018 the portion of the Muna Regency Regional Expenditure Budget increased to 1.2 trillion, but the portion of the budget for the tourism sector has decreased to 1.8 billion, Fajar [2]. So based on these data, it can be seen that indeed the Muna Regency government has made efforts to increase to advance the tourism sector, but the lack of budget allocations in the tourism sector is a major obstacle and obstacle to making Muna Regency tourism advanced and can rival advanced tourism others.

Therefore, the marine tourism sector of Muna Regency should get really serious attention from the local government as a form of commitment to develop and advance the region through the tourism sector. Touch is needed and set a special strategy to advance tourism, for example, providing an appropriate portion of the budget, cooperating with investors to invest in building hotels, resorts, infrastructure, airports and so on which these policies are very supportive policies in advancing marine tourism in Muna Regency. 


\section{METHOD}

This research was conducted in Muna Regency, Southeast Sulawesi Province. With the object of research in the Muna Regency Tourism Office as an office / institution that has a major role and responsibility for the research object to be examined. This research is planned to be conducted in December 2019 until January 2020 .

This type of research uses descriptive qualitative research is a method or evaluation approach. Qualitative methods can be used to uncover and understand something behind a phenomenon that is not yet known, Straus and Cobin (2015: 5). The design of this study was chosen with consideration to evaluate the development of marine tourism in Muna Regency. In this study, the evaluation model used is the REM evaluation model (Realistic, Evaluation, Method). The REM evaluation model was chosen because the aspects reviewed in this research model were considered more comprehensive than the other evaluation models. There are three aspects of evaluation in the REM model, namely context evaluation which includes development programs, evaluation of Mechanism which includes facilities / materials / resources that support the implementation of the program, and outcome evaluation, which is evaluation of the results of implementing development programs. This research is focused on evaluating the development of marine tourism in Muna Regency in terms of context, mechanism, and outcome aspects.

Pawson and Tilley [3] show that the realistic evaluation method approach is a research logic, guided by three themes of realistic evaluation strategies. These realistic evaluation strategy themes increase the specificity of our understanding of the mechanism through which a program achieves change; intensifying understanding of program contexts that influence program mechanisms; and expand the accuracy of forecasting program results. This "realistic explanation triad" seeks to open the "black box" of the program mechanism. 


\section{RESULTS}

\section{Understand The Work Process}

Understand the work process is the initial stage in carrying out an evaluation of the development of marine tourism in Muna Regency. According Ahyari [4], understanding the process is a way, method or technique for the implementation or implementation of a particular thing. While the notion of work according to "work is to do something". Another opinion about the notion of work put forward [5], "work is the process of creating or forming new value in a unit of resources, changing or adding value to a unit of means of meeting existing needs".

Based on some of the above understanding of the process and work, the researcher can conclude that the definition of the work process in question is a way to understand work methods or techniques for the implementation or implementation of a particular thing. At this stage, researchers must understand how the development of marine tourism in Muna Regency is. The process of developing marine tourism in Muna Regency is strongly influenced by local government policies in this case by the Muna Regency Tourism and Culture Office. Muna Regency maritime tourism development policy is implemented based on existing legislation so that by referring to the existing rules it will certainly make it easy for the Muna Regency Tourism and Culture Office to carry out its work tasks in formulating strategies and policies.

The strategies and policies in the Muna District Tourism Office strategic plan are the Office strategies and policies to achieve the medium-term goals and objectives of the Muna District Tourism Office that are aligned with the regional strategies and policies, as well as priority program plans in the draft Regional Medium-Term Development Plan. Muna District Tourism Office's medium-term strategy and policy shows how to achieve the goals, mediumterm targets and target performance outcomes of the Regional Medium-Term Development Plan priority programs that are the tasks and functions of the Tourism Office. The strategies and policies in the Tourism Office Strategic Plan subsequently become the basis for the formulation of the activities of the Muna Regency Tourism Office for each priority program for the Regional Medium-Term Development Plan which is the duty and function of the Muna Regency Tourism Office. Based on the goals and objectives above, several strategies and policy directions have been selected to achieve them: 
Table 1

Strategy and Policy Direction of Muna Regency Tourism Office

\begin{tabular}{|c|c|c|c|}
\hline Goals & Target & Strategy & Arah Kebijakan \\
\hline \multirow{3}{*}{$\begin{array}{l}\text { Develop and } \\
\text { Preserve the } \\
\text { Regional } \\
\text { Tourism } \\
\text { Potential and } \\
\text { increase visits } \\
\text { traveler to } \\
\text { Muna } \\
\text { Regency }\end{array}$} & $\begin{array}{l}\text { Increased Tourism } \\
\text { and Supporting } \\
\text { Infrastructure }\end{array}$ & \begin{tabular}{|l} 
Improved \\
Destination \\
Development
\end{tabular} & $\begin{array}{l}\text { Meningkatkan } \\
\text { Pengembangan } \\
\text { Destinasi }\end{array}$ \\
\hline & $\begin{array}{l}\text { Increased } \\
\text { Development of } \\
\text { Tourism Marketing }\end{array}$ & $\begin{array}{l}\text { Increased } \\
\text { Development of } \\
\text { Tourism Marketing }\end{array}$ & $\begin{array}{l}\text { Improving } \\
\text { Tourism Marketing } \\
\text { Development }\end{array}$ \\
\hline & $\begin{array}{l}\text { The Improvement } \\
\text { of Creative } \\
\text { Economy }\end{array}$ & \begin{tabular}{|l|} 
Improvement \\
Creative Economy \\
Development
\end{tabular} & $\begin{array}{l}\text { Improvement the } \\
\text { Development of } \\
\text { the Creative }\end{array}$ \\
\hline
\end{tabular}

Source: Muna Regency Tourism and Culture Office

\section{Perform Program Evaluation}

Evaluation is a process not an outcome (product). The results obtained from the evaluation activity is the quality of something, whether it concerns about the value or meaning, while the activity to arrive at giving value and meaning is evaluation. provides an understanding of program evaluation is the process of determining systematically about values, goals, effectiveness or compatibility of something in accordance with predetermined criteria and objectives.

In this study program evaluation was carried out using a C-M-O (ContextMechanism-Outcome) configuration approach. As Pawson and Tilley [3], realistic evaluations empirically examine each $\mathrm{C}-\mathrm{M}-\mathrm{O}$ configuration and produce findings that propose types of $\mathrm{C}-\mathrm{M}-\mathrm{O}$ that can work in maintaining a program that results in achieving program results. Therefore, program implementers are not only presented with findings relating to cause and effect or generalizations that do not meet requirements as is the case with other approaches, but are presented with certain C-M$\mathrm{O}$ menus that are ideal for program success. The performance evaluation program conducted by researchers at the Muna Regency Tourism and Culture Office can be seen as follows:

\section{Program Specifications 1: Tourism Destination Development Program}

Tourism destination programs / policies have a policy direction to improve the development of Muna Regency marine tourism destinations based on the Minister of Tourism Regulation No. 29 of 2015-2019 point 1 concerning the Ministry of Tourism Strategic Plan, namely Developing tourism destinations that are competitive, environmentally and culturally oriented in increasing national, and regional income

\section{Context developed by the department:}

a) Increased tourism imaging 
b) Development of leading tourism

\section{With the following mechanism:}

a) Develop areas or tourist sites that have potential and have a pretty good community readiness, this step is called the Regional Tourism Area

b) Developing tourist attractions by being made into a regional package in which there is more than one marine tourism object, this step is called the Regional Tourism Strategic Area

c) Form a cross-sectoral regional tourism development coordination team by involving stakeholders including the Public Works Office, the Health Office, the Education Office, the Environmental Office, the Ministry of Communication and Information, the Regional Development Planning Agency and several Investors.

d) Development of a tourist information center and its equipment at the Bungin Pinungan beach in Towea

e) Build dive centers and equipment at the Bungin Pinungan Towea beach attraction

f) Compile profile $3 \mathrm{~A}$

\section{Lead to the following results:}

a) The development of wista regions or places that have potential and hav

b) good community readiness, including:

\section{Program Specifications 2: Tourism Marketing Development Program}

Tourism marketing programs / policies have a policy direction to improve the development of marine tourism marketing in Muna Regency based on the Minister of Tourism Regulation No. 29 of 2015-2019 point 3 about the Strategic Plan of the Ministry of Tourism, which is to develop tourism marketing synergistically, excel, and is responsible for increasing domestic tourist trips and foreign tourist visits so that they are competitive in the international market

\section{Context developed by the department:}

a) The Promotion of Nusantara Tourism at Home and Abroad

\section{With the following mechanism:}

a) Publicizing tourism by involving and utilizing media such as TV shows, Facebook, Instagram, Twitter, fixed media and online media as an effort to increase marine tourism promotion in Muna Regency

b) Involving tourism communities as communities that help promote tourism

c) Participate and be directly involved in the Southeast Sulawesi even

d) Participate and be actively involved in JKPI activities (Indonesian Heritage City Network)

e) Conducting socialization and cultural vestifal to strengthen the social culture of the surrounding community 


\section{Lead to the following results:}

a) Implementation of Pariwista publications by involving and utilizing media both TV shows, Facebook, Instagram, Twitter, fixed media and online media as an effort to increase the promotion of marine tourism in Muna Regency

b) Involvement of tourism communities as communities that help promote marine tourism

c) The implementation of muna regency marine tourism promotion through Southeast Sulawesi

d) The implementation of marine tourism promotion in Muna Regency through Indonesian Heritage City Network

e) The implementation of socialization and cultural festivals that lead to changes in community behavior that slowly improves from a closed attitude to be open because of the intensity of communication with people who are outside them

\section{Program Specifications 3: Creative Economy Development Program}

Creative economic programs / policies have a policy direction to improve the development of the creative economy of marine tourism in Muna Regency based on the Minister of Tourism Regulation No. 29 of 2015-2019 point 2 about the Ministry of Tourism Strategic Plan, which is developing tourism industry products and services that are internationally competitive, increasing business partnerships, and being responsible for the natural environment and social culture

\section{Context developed by the department:}

a) Development of artwork

b) Development of tourism awareness groups

\section{With the following mechanism:}

a) Conduct training and HR training related to travel awareness

\section{Lead to the following results:}

a) Implementation of training and training of 560 people related to tourism awareness by obtaining certificates of 560 people

\section{Analyzing The Gaps}

Gap analysis is an analysis of the gap between the list of business needs, which is caused by various reasons. So that an effort is needed to identify which parts may have gaps, because it is impossible to find a part that is $100 \%$ fit or perfect. The opinion of Bens [6], gap analysis has a meaning that is identifying missing steps needed to achieve the goal. Gap analysis is a planning tool that creates a shared view of what needs to be done to eliminate the gap between the present and desired future conditions. Bens [6], argues that the purpose of gap analysis is to encourage realistic reviews from now on and help identify things that need to be done to arrive at future desires. 


\section{IV.DISCUSSION}

Nugroho, in his premise, said that every policy must be evaluated before it is replaced, so there needs to be a clause "can be replaced after evaluation" in every public policy. This needs to be used as a reference because, first, to avoid the bad habits of public administration in Indonesia who often apply the principle of "replace officials, must change regulations". Second, so that every policy is not replaced only because of "desire" or "taste" of officials who were then authorized

Based on interviews conducted with Amiruddin Ako, S.Pd., M.Sc as the Head of the Muna Regency Tourism and Culture Office he said that the background of the development of marine tourism in Muna Regency is that marine tourism has extraordinary potential and is natural and has a beautiful sea. not good when with other areas such as Wakatobi, Raja Ampat or other tourist areas so that the potential of marine tourism which is owned by Muna Regency if it can be maximized can become one of the mainstay commodities of the region. Meanwhile, according to Darwi, S.Pd., M.Si as Head of the Tourism Destination Development Division he said that, the development of marine tourism in the Muna Regency was based on the Regional Tourism Development Master Plan (RIPPARDA) so that based on this, the regions wished to encourage the potential of marine tourism in order can be developed.

\section{Development Program Improvement Initiative}

The initiative to increase the development program is a plan of development activities based on the findings of the existing gaps. The findings are based on the results of interviews with the Tourism Office staff involved in formulating a marine tourism development policy program. Based on the findings, improvements can be identified.

\section{Increased Budget Development}

a) The Office builds a strong commitment with the regions through the Regional House of Representatives for budget alignments so that the Regional Expenditure Budget Members can provide a portion that is in line with the needs of the Tourism Office in supporting planned programs given that the budget portion of the Regional Budget is very minimal and limited

b) The office needs to be skilled, careful, and must be able to compile proposal documents for the budget and meet all the requirements requested by the ministry so that all proposed programs can be calibrated properly

\section{Improvement of Development Management}

a) The local government through the tourism office is building a strong commitment to integrating the entire range of regional development organizations in working and supporting tourism development, both the Public Works Office, the Transportation Office, the Police, the Office of Health, the 
Office of Education, the Office of the Environment, the Ministry of Communication and Information, the Regional Development Planning Agency and some investors

b) Through local regulations related to the establishment of an official tourism village can take advantage of the momentum for locations or fostered villages such as fishing villages

c) Dinas needs to improve the management of user charges properly and strictly with steps:

- through the village government in collaboration with the department to make a perdes in the management of levies collection

- The Office manages the management of fees by giving it to third parties (investors) for collecting fees

- Office of improving levies collection management through digital management so that online levies are carried out for the sake of transparency of levies collection to avoid dishonest management

d) Dinas needs to learn about the success of the management and development of marine tourism villages through comparative studies

\section{Increased Development of Community Awareness}

a) The Office Strengthens the socio-culture of the surrounding community through intense socialization and cultural vestifal so as to give birth to the awareness and a sense of belonging of the community (feelings of love for tourism objects so that people feel they have ownership) so that they can slowly encourage community awareness to be better prepared for how to care for destinations regarding about cleanliness and maintaining the facilities that have been given to them

b) Disan needs to organize or improve the institutions that manage the marine tourism sector through counseling and training

\section{Enhancing the Development of Community Empowerment}

a) Strengthen and maximize tourism awareness groups to meet standards as set by the government by providing a special budget to be able to finance 15 people / tourist destinations as honorary staff

b) A necessity for the tourism office to make better arrangements by providing special places for traders through localization

c) Dinas can work with MSMEs to form business groups of art and culture of the maritime community

\section{Improvement of the Regulatory Program}

a) With the formation of local regulations on the determination of several villages as tourist villages, the local government must commit to memorsikan special budget both from the state budget and regional budget.

b) The local government builds cooperation and strong commitment related to the determination of several villages as tourist villages through the Empowerment 


\section{CONCULSION}

Research on evaluating the development of marine tourism in the Muna Regency of Southeast Sulawesi aims to evaluate the development of marine tourism through evaluation analysis of programs that have been planned and implemented by the department by using an evaluation approach (realistic evaluation method configuration context-mechanism-outcome). So based on the background of the problem, theories that support, the methodology of the analysis tools used, the conclusions can be obtained as follows:

1. Based on the research discussion, the development of marine tourism in Muna Regency is strongly influenced by policies and regulations that have been made and implemented by the regional government and ministries.

2. The results of the evaluation of the development of marine tourism in Muna Regency through the analysis of the Context and Mechanism evaluation can be obtained:

a) Several development programs that have been carried out by the Office of Tourism and Culture, both destination development, marketing development and creative economic development programs have been successfully implemented.

b) The Department of Tourism and Culture has several gaps that must be corrected from upstream to downstream in order to achieve advanced and reliable management and development of marine tourism.

3. There are recommendations to overcome gaps that hinder the process of developing marine tourism in Muna Regency, namely:

a) Improving the management system of the Tourism Office by ensuring policies, goals and strategies as well as integrating and including development gaps points so that they can be the focus of improvement in the Tourism Office

b) Improving the implementation of development programs through the work process of the Department of Tourism by including gaps as a focus for improvement and supervised directly by the Regent and Head of Office. 


\section{REFERENCES}

[1] Agus. (2016). DPRD Setujui APBD Muna Rp1,1 Triliun Lebih. Seputar Sultra. Retrieved from https://sultra.antaranews.com/berita/286432/dprd-setujui-apbdmuna-rp11-triliun-lebih

[2] Fajar. (2017). SUARA MUNA Anggaran Pengembangan Wisata Muna Cuma Rp 3,5 Miliar. Retrieved from http://butonpos.fajar.co.id/anggaranpengembangan-wisata-muna-cuma-rp-35-miliar/

[3] Pawson, R., Tilley, N., \& Tilley, N. (1997). Realistic evaluation: sage.

[4] Ahyari, A. (2002). Manajemen Produksi dan Pengendalian Produksi. Yogyakarta: BFE.

[5] Ndraha, T. (1991). Dimensi-dimensi pemerintahan desa: Bumi Aksara.

[6] Benz, H. M., Herman, M., Tarr, A. C., Hayes, G. P., Furlong, K. P., Villasenor, A., Rhea, S. (2011). Seismicity of the Earth 1900-2010 New Guinea and vicinity (2331-1258). Retrieved from

[7] Hetifah, S. (2003). Inovasi, Partisipasi dan Good Governance: 20 Prakarsa Inovatif dan Partisipatif di Indonesia.

[8] Ife, J., \& Tesoriero, F. (2008). Community development: Alternatif pengembangan masyarakat di era globalisasi. Yogyakarta: Pustaka Pelajar.

[9] Jones, C. O. (1984). An Introduction to the Study of Public Policy, California: Wadsworth: Inc.

[10] Machendrawaty, N., \& Safei, A. A. (2001). Pengembangan masyarakat Islam: dari ideologi, strategi, sampai tradisi: Remaja Rosdakarya.

[11] Muna, B. P. S. K. (2017). Kabupaten Muna dalam Angka. BPS Kabupaten Muna. 